\title{
Quality of Work Life Towards Organizational Agility Through Millennial Employee Work Engagements as Mediation
}

\author{
Irwan Raharja ${ }^{1}$, Dedi Purwana ${ }^{2}$, Tuty Sariwulan ${ }^{3}$ \\ \{irwan.ira@bsi.ac.id ${ }^{1}$ \} \\ Postgraduate program, management science, Universitas Negeri Jakarta ${ }^{1,2,3}$
}

\begin{abstract}
The shift in leadership from the older generation to the younger generation has now occurred in the Japanese Foreign Capital Company (PMA) organization in Indonesia, causing a shift in value. This research intends to develop conceptual and empirical models, influence work-life quality on organizational agility, and investigate the indirect effect of work-life quality on organizational agility via work engagement. This study uses quantitative methods with survey techniques using a questionnaire through 380 samples in the millennial age range at Japanese foreign capital companies in several industrial areas in West Java. The AMOS version 24 software was used to analyze the data using structural equation modeling (SEM). The results showed that the work engagement variable as mediation was proven positively and significantly influenced the quality of work-life and organizational agility. Policy implications that can be recommended for Japanese foreign capital companies in West Java are to increase work engagement and organizational agility as well as maximize the quality of work life. By increasing work engagement and organizational agility, Japanese Foreign Capital Companies will survive and compete in Indonesian.
\end{abstract}

Keywords: Millennials, organizational agility, quality of work-life, work engagement

\section{Introduction}

Millennials fill around $40 \%$ of the workforce in Indonesia, who in the future will be the successors and replacements for the current leaders. Japanese PMA companies in Indonesia have also experienced a shift in the leadership generation from the older generation to the younger generation (HRPA member survey September 14-28, 2016). The formulation of the problem in the study is whether there is an effect of quality of work life on organizational agility with work engagement as a mediating variable in Japanese PMA companies in West Java. This study aims to find a conceptual model by analyzing the influence of quality of work life on the agility of Japanese PMA company organizations in West Java with work engagement millennial employee as mediation, and will provide an overview of the conditions of the millennial workforce working in Japanese PMA companies.

Thus, this study will contribute to policies relating to human resources and the professional duties of an employee in the manufacturing industry. From a number of previous studies [1][6]. In addition, this study has a number of novelties that distinguish it from previous studies. First, from the aspects of the object and subject of the study, where this research was conducted at companies engaged in the manufacturing industry in Japanese PMA companies in West Java 
and took millennial employees as samples. Previous studies generally took the object of employees of various ages, while this study was specifically for millennial ages. Previous research only had similarities in one or two variables, and this study involved millennial employee work engagement as an intervening variable.

The novelty of this research is that the work engagement variable of millennial employees as a mediating variable can increase the effect of the indirect relationship between the Quality of Work Life variable on Organizational Agility. There are still not many researches on Japanese PMA companies that analyze the quality of work life and its effect on work engagement in organizational agility efforts. The mediation variable analyzed, namely the work engagement of millennial employees, will be different from the results of previous studies. This study focuses on variables that are thought to have an influence on the work engagement of millennial employees and the organizational agility of Japanese PMA companies. The variable that influences it is the quality of work life in Japanese PMA companies in several industrial areas in West Java Province. The problem in this study is based on a question whether the quality of work life of millennial employees has a positive effect on organizational agility in Japanese PMA companies with work engagement as mediation. The final objective of this research is to study organizational development in the context of the company's sustainability in running its business by having more and different advantages from other organizations. This model in this study is a model of causality or relationship and influence. The analysis used Structural Equation Modeling (SEM) which is operated through the AMOS version 24 software to test the hypothesis.

\section{Method}

This study uses a quantitative approach. The survey was conducted using google form of 380 respondents who are millennial employees aged between 19 and 40 years at Japanese PMA manufacturing companies in West Java Province (Bekasi Regency, Bekasi City, Karawang Regency, Karawang City, Purwakarta Regency and Subang Regency). which includes the automotive, electronics, chemical, food and beverage, plastic and metal industries. The instrument used to obtain research data was carried out using a five-scale questionnaire (Linkert scale). Compiled based on the theories that have been synthesized for each variable, conceptual definitions, operational definitions, dimensions and indicators.

The model used in this study is a model of causality or relationship and influence. To test the hypothesis in this study, the analysis technique used is the analysis of Structural Equation Modeling (SEM) which combines path analysis with factor analysis which is operated through the AMOS version 24 software.

\section{Results and Discussions}

The research results and discussion are based on the data analysis from questionnaire using the AMOS version 24 software. 


\subsection{Results}

\subsubsection{Validity and reliability}

The results of the validity and reliability test of the research variables are shown in Table 1 and Table 2.

Table 1. Results of Test Validity of Research Variables

\begin{tabular}{lllll}
\hline Variable & Coefficient Correlation & Significance & Cut of Value & Information \\
\hline X1 Quality of Work Life & 0.681 & 0.000 & 0.05 & Valid \\
Y1 Work Engagement & 0.472 & 0.000 & 0.05 & Valid \\
Y2 Organizational Agility & 0.611 & 0.000 & 0.05 & Valid \\
\hline
\end{tabular}

Table 2. Results of Test Reliability of Research Variables

\begin{tabular}{lllll}
\hline Variable & Number of instruments & Cronbach's Alpha & R table & Result \\
\hline Quality of work life & 27 & 0.757 & 0.6 & Reliable \\
Work Engagement & 12 & 0.710 & 0.6 & Reliable \\
Organizational Agility & 12 & 0.751 & 0.6 & Reliable \\
\hline
\end{tabular}

All instruments are appropriate to use, based on the results of the validity and reliability tests being high.

\subsubsection{SEM analysis results}

SEM analysis results are presented in Table 3. Testing the Research Hypothesis are presented in Table 4.

Table 3. Results of Testing the Feasibility of the Research Model

\begin{tabular}{llll}
\hline Goodness of Fit Index & Cut off Value & Model Test Results & Information \\
\hline Chi-Square $(\mathrm{df}=109)$ & $<134.368$ & 303.970 & Good \\
Probability & $\geq 0.05$ & 0.059 & Good \\
CMIN/DF & $\leq 2.00$ & 1.139 & Good \\
AGFI & $\geq 0.90$ & 0.930 & Good \\
GFI & $\geq 0.90$ & 0.943 & Good \\
TLI & $\geq 0.95$ & 0.992 & Good \\
CFI & $\geq 0.95$ & 0.993 & Good \\
RMSEA & $\leq 0.08$ & 0.019 & Good \\
\hline
\end{tabular}

Based on the analysis results (Table 3), the analyzed model was cursive model with a sample size of 380 . Chi-Square value $=303.970$ with $\mathrm{df}=265$ and probability 0.000 . The ChiSquare results show that the null hypothesis which states the model that the same as empirical data is accepted which means the model is fit.

\subsubsection{Hypothesis test}

Based on Table 4, hypothesis testing can be explained as follows. 
Table 4. Testing the Research Hypothesis

\begin{tabular}{|c|c|c|c|c|c|c|}
\hline Variable & & & Estimate & Standard Error & Critical Ratio & Probability \\
\hline WE & $\begin{array}{l}<-- \\
\end{array}$ & QWL & 0.118 & 0.038 & 3.084 & 0.002 \\
\hline $\mathrm{OA}$ & $<---$ & OWL & 0.144 & 0.054 & 2.678 & 0.007 \\
\hline OA & $<---$ & WE & 0.468 & 0.154 & 3.044 & 0.002 \\
\hline
\end{tabular}

The Critical Ratio (CR) value of 3.084 with a probability of 0.002 is the estimation parameter for examining the effect of Quality of Work Life on Work Engagement. As a result, because the probability value was less than 0.05 , the Quality of Work Life variable was found to have a positive and significant impact on Work Engagement. The findings demonstrated that the theory was put to the test.

The CR value of 2.678 with a probability of 0.007 is the estimation parameter for examining the effect of Quality of Work Life on organizational agility. As a result, because the probability value was less than 0.05, we may conclude that the Quality of Work Life variable has a positive and significant impact on organizational agility. The findings demonstrated that the theory was put to the test.

The CR value of 3.084 with a probability of 0.002 is the estimation parameter for assessing the effect of Quality of Work Life on Work Engagement. Because the probability value was less than 0.05 , the effect of Quality of Work Life on organizational agility via Work Engagement was $0.238 \times 0.246=0.059$, resulting in a total effect of 0.211 . According to these findings, the indirect influence outweighs the direct effect. As a result, the Work Engagement variable has been shown to be a positive and significant mediator between Quality of Work Life and Organizational Agility. The findings demonstrated that the theory was put to the test.

\subsection{Discussions}

The ability of an organization to survive and improve in an environment of constant and unpredictable change is referred to as organizational agility [7]. or it can refer to the ability to move quickly, to move quickly and easily, and to think quickly and wisely [8]. It is hoped that the organization will gain a competitive edge by being able to face and adapt to changing business situations with this skill. This is certainly a necessity for the company to continue in any business environment. Japanese Foreign Capital Companies in West Java are customeroriented by paying attention to employee needs in an effort to improve the quality of employee resources for a more conducive work environment.

Based on the results of SEM analysis, research findings show that quality of work life encourages work engagement and agility of Japanese foreign capital companies in West Java, which means that Japanese foreign capital companies in West Java have a better quality of work life by carrying out activities that improve relationships. employees with a work environment will increase the agility of Japanese foreign investment companies in West Java. This means that if the quality of work life increases, the work engagement as willingness to try earnestly in doing the job, as well as persistence and persistence in facing difficulties in work [9] and agility of Japanese foreign capital companies in West Java will also increase.

According to the findings of the study, the mediating variable of millennial employee job engagement can boost the indirect association between quality of work life and organizational agility when compared to the direct relationship between each component and organizational agility. This is due to the fact that various indicators in the quality of work life variable, such as job security, occupational health, compensation, and pride, would offer millennial employees' enthusiasm and connection to their jobs. 
Good work engagement will make vigor, work dedication and high absorption, and have an impact on employee competence, speed and responsiveness of employees in the context of employees and companies' ability to adapt to changes in the company's internal and external environment in an effort to sustain business in Japanese Foreign Capital Companies. is in West Java.

\section{Conclusion}

Through job engagement, Quality of Work Life has a positive and significant impact on Organizational Agility. The indirect effect of work life quality on organizational agility, as mediated by job engagement, was found to be larger than the direct effect. As a result, it can be concluded that the variable Work engagement as a mediator has been shown to have a positive and significant impact on Organizational Agility.

\section{Acknowledgement}

The author would like to thank Dr. Mukhtadi, MM, and Agung Dharmawan Buchdadi, MM, Ph.D as experts who have validated this research instrument.

\section{References}

[1] I. Raharja, D. Irwati, and S. Hasibuan, "Design of performance measurement in Indonesia plastics seeds coloring company by using stakeholder perspective PRISM,” Int. J. Eng. Adv. Technol., vol. 8, no. $5,2019$.

[2] Kurniawati, C. E. "Pengaruh Quality of Work Life Terhadap Work Engagement Dan Organizational Citizenship Behaviour Pada Perusahaan Elektronik Di Surabaya”. Agora, 6(2), 2018

[3] Nafei, W. A. "The Effect of Organizational Agility on Quality of Work Life: A Study on Commercial Banks in Egypt". International Journal of Business and Management, 11(6), 271-285, 2016

[4] Nafei, W. A, "The Mediating Role of Organizational Identification in the Relationship between Quality of Work Life and Organizational Agility: A Study on Menoufia University Hospitals". International Business Research, 11(1), 184-203, 2018

[5] Wardani, L. M. I., \& Anwar, M. S. "The role of quality of work life as mediator: Psychological capital and work engagement". Humanities \& Social Sciences Reviews, 7(6), 447-463, 2019

[6] Saha, N., Gregar, A., \& Sáha, P. (2017). "Organizational agility and HRM strategy: Do they really enhance firms' competitiveness?”. International Journal of Organizational Leadership, 6, 323-334, 2017

[7] Maskell, B. (2001). The age of agile manufacturing, supply chain management. An International Journal, Vol. 6, No.1, pp. 5-11.

[8] Hornby, A.S. (2000). Oxford Advanced learners' dictionary of current English, Sixth Edition, Oxford University.

[9] Bakker, A. B., \& Albrecht, S. "Work engagement: current trends". Career Development International, 2018. 